\title{
Investor and (Un)Accountability of The Supervisor in Self-Construction of a Single-Family House
}

\author{
UDK: 35.078.3:69 \\ Mojca Klemenčič Manič \\ Ingra Stanislav Klemenčič, s. p. \\ mojca.klemencic@gmail.com \\ Zoran Cunk \\ Ministry of the Interior, Police, Police Directorate Maribor \\ zoran.cunk@gmail.com \\ Štefan Bojnec \\ University of Primorska, Faculty of Management \\ stefan.bojnec@fm-kp.si,stefan.bojnec@siol.net
}

\section{ABSTRACT}

The paper addresses the role and importance of a supervisor and his controlling bodies in self-construction of a single-family house. We study his accountability in actions, which must be in accordance with both statutory provisions and ethical-moral rules of social responsibility. In determining his accountability for construction execution we mainly focus on the findings of his monitoring bodies, the professional organizations (the Slovenian Chamber of Engineers and the Chamber of Architecture and Environmental Planning of Slovenia) and the building inspectorate. The Construction Act and certain rules, which clearly specify obligations of supervisors in self-construction and also provide sanctions, are critically discussed. Construction is always accompanied by various interests and the legislator must ensure minimal safety and construction standards, as well as living standards for all single-family houses, in order to ensure socially responsible actions of all participants in a project. In practice the status and role of the supervisor from the investor's point of view is not clear.

Klemenčič Manič, M., Cunk, Z. \& Bojnec, Š. (2011).

Investor and (Un)Accountability of The Supervisor in Self-Construction

of a Single-Family House. Uprava IX(3), 35-62. 
Key words: self-construction, supervisor, the Slovenian Chamber of Engineers, the Chamber of Architecture and Environmental Planning of Slovenia, Construction Inspectorate, social responsibility

JEL: H42, L74, L98

\section{Introduction}

The investor is a legal or natural person, who orders or executes the construction of a building (Point 4.1 of Article 2 of the Construction Act (CA), Official Gazette (OG) of the Republic of Slovenia (RS), No. 1 10/02 with modifications - hereinafter CA-1). According to CA-1, construction of a building covers designing, constructing and maintaining (Article 1 of CA-1). A building is a structure with one or more rooms, in which a human may enter and are intended for living or business accommodations (Point 1.1 of Article 2 of the CA-1). CA- 1 enables the investor self-construction of a single-family house. ${ }^{1}$ Studying the rationality of investors in construction or their open illegal actions in self-construction has revealed (Klemenčič Manič, 2011) that it is essential to introduce better social responsibility for all participants in self-construction of singlefamily houses, not solely for the investor. Construction of a single-family house may be described as an investment process, despite of a relatively low investment value, if compared to other construction projects. Every investment process includes investors and contractors, who must constantly plan and monitor profit or loss, expenses, cash flows, deadlines and quality (Slana, 2010, p. 8). The key issue is, whether the investor, who undertakes self-construction and is therefore also the (only) contractor, even has sufficient knowledge to manage and carry out this process on his own or with help of other participants. The term knowledge covers also skills from various crafts. The goal of this process should not only be savings in execution expenses (fulfilling economic rationality), but mainly ensuring construction of appropriate quality, which meets the criteria of social responsibility.

Along with the investor, participation in construction is only possible for neighbours and family members. Mandatory professional participants

1 Self-construction means that the investor as a natural person constructs a structure on his own, with help from family members or neighbours, or that a society constructs a structure with the help of its members, which it needs for the purpose of its residence or for conducting its activities (Point 8.2 of Article 2 of the CA-1). 
are the project leader for acquiring a building permit and the supervisor. This paper studies the accountability of the supervisor, who represents the business entity or the natural person, who acts on his behalf. Therefore it is crucial to answer the question, whether (or how) the supervisor may assist the investor in construction and what are the essential characteristics of this participant in construction.

The investor could often be characterized with the term layperson (Plavšak, 1998, pp. 16-17), with the characteristics of the contractual party which does not need special professional expertise in regard to the subject of the contract, since he entrusted the execution of services, needed for meeting the contractual result, to a person, who has this professional expertise or offers services, including such expertise. The supervisor has the characteristics of a professional person (Plavšak, 1998, page 16) with appropriate professional expertise for conducting services, which are the subject of the contract and are required for construction and for which the contract giver (usually the investor) does not have sufficient expertise or has such expertise, but wishes not to handle individual professional issues regarding construction for any given reason.

The investor must sign a contract for construction monitoring with the supervisor. Thus the civil liability relationship between both construction participants is established. But the supervisor may violate ethical-moral provisions and provision of positive law. These actions indicate criminal conduct (minor and criminal offence) and also imply socially (ir)responsible implementation of construction activities. The issue we are facing is, whether supervisors are aware of their responsibilities and whether the authorities properly detect the occurrence of illegal actions, which would enable the investor to rationally decide whether to include a supervisor in the construction process.

The dialectics and systems theory (Mulej, 2000, p. 63) enables better understanding for reaching sufficient and necessary integrity and warns of and stands for the fact that actions of people and organizations should be considered in regard to modern needs of mankind, meaning social responsibility. Concerning this, we shall consider three issues. First, socially responsible actions (Carroll \& Buschholz, 2000, p. 750) of the investor upon the inclusion of the supervisor. Second, social responsibility of the construction supervisor and his actions for acting in accordance with legal acts in force and acting in accordance with the moral-ethical 
perspective of a certain society. Third, focusing on the occurrence of criminal conducts as indicators of meeting the legal and ethical input of social responsibility (Cunk, 2010, p. 6).

Our research problem is evaluating the starting points and finding an answer to the research question, whether the supervisor acts socially responsible and mainly follows ethical-moral norms and provisions of positive law; and whether institutions of the national administration are successful and effective with their monitoring apparatus, since rules and criteria in this field are not entirely clear and have often been modified under pressure of different lobbies. The basic purpose is evaluating the segment of the supervisors' social responsibility during the selected period (2006-2010) on the territory of Slovenia. Special attention is given to the role and importance of the supervisor and his monitoring bodies in construction. In order to achieve this, we shall use:

- the description method for describing facts concerning the work of supervisors, which are worth considering in order to understand the reasons for the current situation and their consequences, as well as for developing new findings;

- the analysis and synthesis method for defining research starting points and perspectives, as well as for developing new findings and conclusions; and

- the inductive method for empirical identification of facts during research, from which we shall develop conclusions of a general theoretical type.

The basic goal is to portray the occurrence of criminal conducts of construction supervisors in Slovenia with a critical analysis, supported by an analysis of existing secondary data. The key novelty and a substantial contribution to science is the evaluation and presentation of the criteria for the investor's trust in the supervisor of the self-construction of a singlefamily house and the accompanying research question of the supervisor's personal and social (un)accountability in self-construction of a singlefamily house.

\section{Importance of the supervisor}

Even though the term "self-construction of a single-family house" implies that the investor is the only person in the construction process, positive law also defines the supervisor as a mandatory participant 
in the process: the supervisor is a legal or natural person, whose economic activity is offering construction monitoring services (Point 4.4 of Article 2 of the $(A-1)$ and who meets the conditions of the CA-1 for project leaders or contractors (Article 30 of the CA-1). This person is usually the investor's project leader.

It needs to be emphasized that along with the investor, the supervisor also strives towards realizing an economic goal (usually achieving profit as a difference between the contractual price and actual costs). Therefore the investor's and supervisors' professional interests may be diametrically opposite (Plavšak, 1998, pp. 18-19). But this economic goal is not the only mandatory real-estate function, since the Constitution of the RS IOG of the RS, No. 33/91) in Article 67 defines that the law determines the method of acquiring and using property in a manner which ensures its economic, social and ecological function. The content of Article 15 is also to be considered. It determines that human rights and fundamental liberties are limited only by rights of others, amongst which is the limitation due to public interest. The supervisor, who performs supervision as an economic activity, is bound by the Constitution of the RS, not to perform economic activities in contrast to public benefit (Article 74).

The investor and the construction supervisor are individually and according to rights and obligations, as determined by CA-1, obliged to ensure that buildings and their individual parts are reliable, in accordance with spatial planning acts and recorded, as well as that they enable access, entrance and use without physical or communicational barriers to physically challenged individuals (Article 18 of the CA-1). Each participant in self-construction is therefore responsible for the reliability of the building in its entirety.

The CA-1 (Article 32) also determines damage liability. As opposed to the investor, the supervisor must, before commencing activities, acquire damage liability insurance for the entire duration of operations for any damage, which might occur to investors or any third parties as a result of his activities (Article 33 of the CA-1).

Construction supervision is performing professional supervision over a construction site, with which it is checked, whether construction takes place according to the project for acquiring a building permit, on the basis of which a building permit was granted. Supervision is performed over the quality of executed work, construction materials, other materials, 
installations and technological devices, installed into the building, as well as whether the set deadlines for completion are respected on-site (Point 8.3 of Article 2 of the CA-1). Supervision may be carried out on behalf of the investor by a legal or natural person, who meets the conditions for project leaders and contractors set in this law (Article 30 of the CA-1). The investor must ensure construction supervision at the latest on the day of starting preparation works on the construction site, and entrust it to a project leader or a contractor, who does not perform construction on this site (paragraph 1 of Article 85 of the CA-1).

The supervisor must name an accountable supervisor for each construction site under his construction supervision paragraph 1 of Article 86 of the (A-1). This is an individual accountable to the supervisor for the compliance of construction with the conditions from the building permit and for the quality of executed work, in accordance with building regulations (Point 4.4.1 of paragraph 1 of Article 2 of the CA-1). The accountable supervisor controls, whether all modifications and additions occurring during construction are simultaneously listed into the execution project and whether the investor and project leader agree to these changes (paragraph 1 of Article 88 of the CA-1). This provision also undisputedly states that project documentation for acquiring a building permit (ABP) is insufficient for construction, it is meant only for acquiring a building permit. Construction must take place according to the conditions from the building permit, but not on the basis of the project for $A B P$, but rather on the basis of the execution project (EP). This type of project documentation is mandatory for a construction site, since the construction supervisor may perform supervision only on the basis of the EP. ${ }^{2}$ In the first stage the project leader prepares project documentation for ABP for the investor, which is the condition for granting a building permit.

2 But according to the CA-1 this unfortunately does not apply for the so called projectleader supervision. CA-1 imposes the accountable leader of ABP to monitor, whether construction of the building, which he designed, takes place according to $\mathrm{ABP}$ (paragraph 4 of Article 45). But the penalty for not following this provision is not stipulated. The CA-1 does not state anywhere that the investor should notify the project leader for $A B P$ on commencing construction. Often the project leader for $A B P$ is also the supervisor, meaning that he performs project-leader and construction supervision simultaneously. According to the provisions of $C A-1$, this means he is performing the first supervision based on the ABP and the second based on the EP, which is questionable from a professional perspective. The basis for both supervisions should be detailed documentation and this can only be the EP. 
Before commencing work execution, the investor must order the preparation of the EP, according to which work is actually executed. One of the tasks of the contractor (in self-construction this is the investor) is also to execute work on the construction site in accordance with the execution project (Point 2 of paragraph 1 of Article 83 of the CA-1). The project for acquiring a building permit is intended, as it is clear from its title, only for the administrative procedure of acquiring a building permit and not for work execution, since its content is quite limited and does not suffice for construction purposes. From debates on online forums (e.g. podsvojostreho.net) it is clear that many investors do not order the execution project and that many supervisors perform supervision without this documentation, which is unacceptable from a professional perspective. If during construction the accountable supervisor finds any inconsistencies with the execution project or building regulations; any building or other products, installations, technological devices and equipment of inadequate quality; any breaches of set deadlines etc.; he must immediately notify the investor (or the Construction Inspector) and record the findings (and propositions for improvement) into the construction log book and with his signature he also confirms that the recorded data are genuine (paragraphs 2, 3 and 4 of Article 88 of the CA-1). But keeping a construction log book is not mandatory in selfconstruction (paragraph 1 of Article 10 of the Rules on Construction Sites). Therefore the supervisor is unable to record his findings anywhere. Besides, we must not overlook that the supervisors' main (damage) liability is mainly bound to an adequately led construction log book and that his liability in performing construction supervision does not have the nature of liability for real errors, but is rather based on general rules of contractual damage liability (Dobnik, 2011 , p. 10). From this it is undoubtedly clear that the supervisor is able to avoid liability, since there is no written proof of his (un)revealed errors in self-construction.

When the investor, along with the accountable supervisor and the accountable ABP project leader, determines that construction has been carried out in accordance with the building permit, so that the building is usable, and that the executed work project (the latter is not required for a single-family house - paragraph 3 of Article 101 of the CA-1) has been prepared, he must, in accordance with paragraph 1 and 2 of Article 89 of the CA-1, submit a request for acquiring an operating permit to the administrative body, which granted the permit, within eight days. 
The Chamber of Engineers (CE) (Leban, 2011) determines that the supervisor's authority deriving from his licence is limited and that he must therefore name assistants - accountable supervisors of individual works from other professions, even when building a less challenging building (all self-constructed single-family houses). The SCE therefore justly expects that supervision over building constructions may be carried out by a construction engineer, over electrical installations by an electrical engineer, etc. But since the CA-1 does not stipulate at any point who may perform supervision, it is considered that the architect or the construction engineer may also issue a statement, such as: "...there were no deviations from the project for $\mathrm{ABP}$ and the granted building permit...that the building is constructed in accordance with regulations..." even though he is not qualified for inspecting electrical, telecommunication or machine equipment or installations (the architect not even for execution of building constructions). The condition for granting an operating permit for a single-family house is, along with this statement of the accountable ABP project leader and the accountable supervisor, only the geodetic plan of the new state of the plot (paragraph 3 of Article 101 of the CA-1). But in practice (Klemenčič Manič et al., 2011) only a few investors acquire an operating permit, since administration costs are too high comparing to the penalties.

A general lack of social responsibility may be explained by the lack of a construction log book and by transaction costs of examining. Since there is no construction log book, the investor is unable to prove anything to the supervisor, because he does not have any written document (except the contract). Even with a contract, the supervisor may excuse himself by claiming that the investor did not notify him about the construction or even that he stated that construction has been stopped. This is why it is difficult to gather information during inspections of single-family houses, which refer to errors in the construction process and liability for them. This is probably also the reason why accurate information on self-construction does not exist. Besides, transaction costs of examining increase with the distance between the supervisor's office and the construction site location. 


\section{Socially (ir)responsible actions of the supervisor}

\subsection{Professional ethics}

Mead (1997, p. 173) emphasizes that individuals, whose cooperation is essential for the functioning of a system as a whole, use their social organism, which as a manifestation form of the community, is not a goal of (co)operation by itself, but rather a starting point and means for achieving synergies. Some of such social forms are also professional organizations. For the purpose of guaranteeing professionalism and protecting public interest in the fields of spatial planning, construction and protecting third parties, two professional chambers were founded in Slovenia (paragraph 1 of Article 108 of the CA-1):

1. The SCE is an independent organization, which combines over 6,000 authorized engineers, participating in construction and in coordinating construction with spatial planning on the territory of Slovenia.

2. In January 2004 architects, urban planners and landscape architects founded an independent chamber, the Chamber of Architecture and Environmental Planning of Slovenia (CAEP). Today the CAEP has over 1,400 members.

Professional organizations generally handle violations of mandatory ethical norms in accordance with their code. Mead (1997, pp. 280-287) emphasizes that the only rule, which ethics can give, is that an individual must rationally consider all the values included in a specific problem. This does not mean he should consider all social values, but rather that the problem determines corresponding values, since it is actual and incorporates actual interests. All these interests need to be thought through and then an action plan is prepared, which thoughtfully considers the problem. Such a collection of interests from ethical and moral perspective is the code, an accepted precise determination of numerous aspects of professional work, which defines essential focus points of work execution of a general nature.

In 2010 the Assembly of the SCE adopted a Code of Professional Ethics for SCE Members. In their work engineers, members of the SCE, must follow the code, which in its preamble, among other things, stipulates that engineers take care of the quality of life and protect public interest, as well as individual interest. Article 1 also clearly determines its 
primary purpose: «ensuring the highest standard of professionalism amongst engineers". Engineers must respect and adequately use applicable national legislation and legislation of the European Union (EU), rules in force, technical rules, generally accepted and in force standards, as well as norms and rules of the profession, according to which they behave in performing their profession and services, which are entrusted to them (Article 2 of the Engineers Code).

The ethical-moral aspect of performing work and tasks of essential participants in construction, for members of the CAEP, is handled by the Code of Professional Ethics for Architects, Landscape Architects and Spatial Planners, which sets principles and rules, according to which they must conduct themselves in their operations (Article 1). In performing his activity, the architect is obliged to find the most suitable solution by following regulations in force, characteristics of the location, available resources and the ecological, contextual and social aspects of proposed solutions (Introduction of the Code).

Both codes are starting points for rules, the violation of which is defined in the disciplinary rulebook as a disciplinary violation.

Following ethical rules of essential participants is monitored and handled by two professional organizations:

1. SCE: In case of disciplinary violations of provisions from the code, engineers are held responsible according to the Disciplinary Rulebook of the SCE. According to the SCE newsletter (GIZ 2011, pp. 6-7) the disciplinary officer of the chamber received 33 reports during the period of 1 January 2010 - June 2011 (26 in 2010 and 7 in 2011), 18 of which he rejected and handled the others (Kocjan, 2011 , p. 8).

2. CAEP: In case of code-violating conduct, they undergo sanctions determined by the Disciplinary Rulebook (OG of the RS, No. 69/10). In practice, after rulings of administrative courts (e.g. UM0010386 and UL003513), some first and second stage decisions were returned to renewed proceedings due to procedural errors.

Some ethical-moral norms present a certain increased hazard compared to the hazard, which derives from any violations of ethical-moral norms and general legal regulations. Therefore there is a 
basis for elevating them to the level of legis plusquamperfectae - minor offence. $^{3}$

\subsection{Minor offences by the supervisor}

A minor offence is any action breaking the law, a government decree and a decision of the local community; which is defined as a minor offence and for which penalties for a minor offence are sanctioned (Article 6 of the Minor Offences Act, OG of the RS, No. 7/02 with modifications - hereinafter MOA-1). The Construction Inspector sanctions the supervisor for a minor offence using fast-track proceedings, if he is violating any restrictions from the Articles of the CA-1. If he determines compulsory execution, the financial penalties for a less challenging building, if the person liable is a legal person, an individual independent entrepreneur and an individual, who conducts business individually, amount 40,000 and up to 80,000 euros (paragraph 1 of Article 148 of the CA-1). All later penalties for pressuring the person liable, if he is not fulfilling his obligations despite issued penalties, are given until the total sum of financial penalties reaches 10 times of the amount of the financial penalty (paragraph2 of Article 148 of the CA-1). It needs to be pointed out that offences concerning construction from the provisions of CA-1 fall under statute of limitation in two years.

Monitoring the execution of stipulated activities of the supervisor according to the CA-1 is performed by the Construction Inspector according to provisions of administrative law, which covers nationally sanctioned material and formal legal rules and principles, which handle actions and conduct of subjects (bodies and clients) in legal-administrative relationships, where there is an actual or potential conflict between public and private interests (Tičar \& Rakar, 2011, p. 41). The Construction Inspector acts according to the Inspection $\mathrm{Act}^{4}$ as an umbrella act for all inspection services in all fields of operation. Thus the Construction Inspector orders with a decree which of the general inspection measures, stated in Article 150 of the CA-1, should be enforced, in order to remedy clear errors. ${ }^{5}$ As a minor offence authority, the Construction Inspector

3 Summarized according to Bele, 2006, p. 53.

4 OG of the RS, No. 56/02 with modifications.

5 Measures are: remedying errors regarding the building, construction or maintenance; stopping further construction, if determined errors are not remedied; banning building 
decides on minor offences (using fast-track proceedings) or forwards bills of indictment to the court. Regarding the role and function of the Construction Inspector it needs to be noticed that MOA-1 does not only enforce the principle of indictment (also propositional, accusatory principle), but according to the official principle proceedings may also commence according to official duty - ex offo (Tratar, 2005, p. 191). Therefore those actions are relevant, which the minor offence authority the Construction Inspector performs during prosecution by himself and within the framework of his jurisdiction (Article 50 of the MOA-1).

Minor offences by the supervisor, which are directly connected with construction of a building, are defined in Article 175 of the CA-1 and minor offences by the accountable supervisors in Article 176 of the CA-1.

A legal person, an individual independent entrepreneur and an individual, who conducts business individually and, according to the provisions of CA-1, acts as the supervisor, is fined for the minor offence, if he/she violates restrictions from Article 175 of the CA-1, with a fine in the amount of 6,000 to 30,000 euros. A fine of 500 to 1,500 euros is also issued to the person liable for the supervisor, who commits any of the actions from Article 175 of the CA-1. A fine of 500 to 1,200 is issued to an individual as an accountable supervisor, if he/she violates restrictions from Article 176 of the CA-1.

Table 1: Measures of Construction Inspectors during the monitoring of construction supervisors in Slovenia, 2006-2010

\begin{tabular}{|l|r|r|r|}
\hline Year & No. of buildings & Issued decisions & $\begin{array}{r}\text { Measures of the minor } \\
\text { offence authority }\end{array}$ \\
\hline 2006 & 268 & 14 & 12 \\
\hline 2007 & 239 & 4 & 13 \\
\hline 2008 & 244 & 6 & 23 \\
\hline 2009 & 245 & 6 & 17 \\
\hline 2010 & 259 & 29 & 12 \\
\hline
\end{tabular}

Source: IRSOP 2008-2010; MOP 2006-2007

Monitoring supervisors is one of the priorities of the Construction Inspectorate, determined with an annual plan for a relevant period (from

usage and banning the installation of construction materials and minerals (150/l-1 to $150 /$ I- 4 of the CA- 1 ). 
2006 to 2010). It is clear from Table 1 that during the period from 2006 to 2010 Construction Inspectors monitored construction supervisors at an average of 251 buildings each year and annually issued an average of 12 decisions for remedying errors and, as a minor offence authority, issued an average of 15 measures for minor offences each year. In 2006 the number of inspected building was highest. Since 2007 it can be once again seen a slight increase and in 2010 the number slowly approaches that of 2006. The number of measures taken by the Construction Inspectorate as a minor offence authority rises from 2006 to 2008 (192\%) and drops to the number from 2006 in 2010. In 2010 Construction Inspectors also forwarded 11 bills of indictment to the competent court. The number of issued decisions has been dropping up to 2010, when, compared to 2006, inspectors issued $107 \%$ more decisions (in average every $9^{\text {th }}$ inspection) (IRSOP 2008-2010, MOP 2006-2007).

In all the years from 2006 to 2010, Construction Inspectors emphasized (IRSOP 2008-2010; MOP 2006-2007) in their reports that with an effective and complete supervision over building construction, which the law mandates for supervisors, the work of Construction Inspectors may be limited only to regular on-site inspections, since the supervisors' duty is complete supervision over the following of the law in construction. From this we could indirectly make out that Construction Inspectors are satisfied with their monitoring of supervisors, since they are able to evaluate and plan their work for each year on the basis of their findings.

While performing his/her work and duties at a construction site, a supervisor may also commit the most severe form of criminal conduct - a criminal offence.

\subsection{Criminal offences by the supervisor}

\subsubsection{Criminal offence in general}

Directly while performing his/her activities at a construction site, a supervisor may commit a criminal offence of causing danger in construction activities, regarding his/her work. A criminal offence as the most severe form of criminal conduct was defined in the Penal Code (PC, in force since 1 November 2008) as unlawful conduct, which the law, due to its threat level, determines as a criminal offence and simultaneously determines its indicators and punishment for it (Article 7 of the PC, OG of 
the RS, No. 63/94 with modifications). PC-1 (OG of the RS, No. $55 / 2008$ with modifications - in force since 1 November 2008) defines it as a person's unlawful action, which the law, due to the mandatory protection of legal values, defines as a criminal offence and simultaneously determines its indicators and punishment for the guilty perpetrator (Article 16 of the PC-1). The PC determined the criminal offence of causing danger in construction activities in Article 318 and the PC-1 defined the substantially intact form of criminal conduct from the PC in Article 315.

The criminal offence of causing danger in construction activities falls among criminal offences against general safety of people and property from paragraph 30 of the PC and PC-1. The primary object of criminal law protection is general safety and the secondary objects of protection against this criminal conduct are human lives and their property. The perpetrator's quilt therefore is not directed towards a specific person or item, but rather towards a more or less indeterminate (lax) circle of people or items (Selinšek, 2007, p. 420). A criminal offence belongs among lifethreatening criminal conduct, since it presents an actual danger for human lives and property of great value.

PC and PC-1 determine punishing a person, who is responsible for planning and monitoring plans, for preparing and leading the construction process, who in doing so acts in contradiction to regulations or generally accepted technical rules and thus causes danger for human lives and property of great value (paragraph 1 of Article 318 of the PC and paragraph 1 of Article 315 of the PC-1). Basic characteristics of signs of the stated fundamental criminal offence are:

- A criminal offence belongs in a group of special criminal offences or delicta propria, since it is especially defined, who may be the perpetrator of this criminal conduct. Paragraph 1 of this Article therefore determines that this is a person, who is responsible for planning and monitoring plans, for preparing and leading the construction process, so also (in certain instances especially) the supervisor.

- A criminal offence is of a blanket nature, since the legislator evokes regulations or generally accepted technical rules. The fundamental regulation is undisputedly the CA-1 with its implementing regulations, while the generally accepted technical 
rules are those rules, which derive from construction science and are used in construction (Deisinger, 2002, p. 802).

- The result of criminal offences is causing actual danger for human lives, which may take place in the form of physical injury, death or causing actual danger for property of great value.

- The perpetrator may commit a criminal offence both intentionally or as a result of negligence.

- The prescribed punishment for criminal offences according to paragraph 1 is deprivation of liberty for up to three years. If an action from paragraph 1 results in physical injury of at least one person or great pecuniary loss, it is punishable by deprivation of liberty for 1-5 years (paragraph 3 of the Article). But if a criminal offence according to paragraph 1 results in death of at least one person, it is punishable by deprivation of liberty for $1-12$ years (paragraph 4 of the Article). Paragraph 2 prescribes a financial penalty or prison for up to one year for a less severe form of criminal offences from paragraph 1 (criminal negligence). If this conduct results in severe physical injury or great pecuniary loss, it is punishable by deprivation of liberty for up to three years (paragraph 3 of the Article), but if this conduct results in death of a person, it is punishable by deprivation of liberty for up to eight years (paragraph 4 of the Article).

- A legal person may also be held responsible for criminal offences in accordance with Article 25 of the Liability of Legal Persons for Criminal Offences Act (OG of the RS, No. 59/1999 with modifications).

The charge for criminal offences of causing danger in construction activities is filed at the competent state prosecutor (Paragraph 1 of Article 147 of the Criminal Procedure Act) or may also be filed at court or the police (who accept it and immediately forward it to the competent state prosecutor). The charge for criminal offences of causing danger in construction activities for which a perpetrator is prosecuted ex officio may be denounced by anyone. In practice the role of "anyone" usually falls to the victim (the investor) or any other person, who believes that certain actions have met the required elements of a criminal offence.

Slightly different conditions for reporting criminal offences apply for public authorities. All public authorities and organizations with public 
authorization are obliged to denounce criminal offences of causing danger in construction activities, if they are notified of it or if they discover it in any other manner. Therefore if a Construction Inspector receives a report, he/she is obliged to forward it to the Office of the Prosecutor or the Police.

Table 2: Persons of full age, for which criminal proceedings at the state prosecutor have concluded, according to the denouncer in Slovenia, 2006-20096

\begin{tabular}{|l|c|c|c|c|c|}
\hline & $\begin{array}{c}\text { No. of } \\
\text { charges }\end{array}$ & Victim & Police & $\begin{array}{c}\text { Inspection } \\
\text { service }\end{array}$ & Other \\
\hline 2006 & 6 & 3 & 2 & $/$ & 1 \\
\hline 2007 & 12 & 5 & 6 & $/$ & 1 \\
\hline 2008 & 21 & 6 & 6 & 7 & 2 \\
\hline 2009 & 16 & 5 & 6 & 1 & 4 \\
\hline 2010 & 11 & 8 & 1 & 1 & 1 \\
\hline
\end{tabular}

Source: SORS, 2011

It is clear from Table 2 that during the years from 2006 to 2010 the Office of the State Prosecutor has concluded 66 charges, from which the victim (the investor) filed $40.91 \%$, the police $31.82 \%$ and inspection services and others (direct discovery of the state prosecutor, other individuals, etc.) $13.64 \%$. While reports by victims are common, the inspection service, as the main authority responsible for monitoring the execution of CA-1 as a blanket norm for criminal conduct, filed $77.78 \%$ of all of its charges in 2008 alone, otherwise there are none or they are very rare (1 or $11.11 \%)$.

In the following text we present characteristics of the occurrence of criminal offences of causing danger in construction activities according to Article 318 of the PC and Article 315 of the PC-1 for the period of 2006 to 2009.

\subsubsection{Occurrence of criminal offences}

In Article 318 of the PC (Article 315 of the PC-1) the legislator defined human lives and property as protected goods in construction of

6 Data for year 2009 are for criminal conduct according to both Article 318 of the PC and Article 315 of the PC- 1 . 
a building, which clearly shows the importance of this field (building construction) and protected goods in this economic activity.

Table 3: Persons of full age, for which criminal proceedings for a criminal offence have concluded ${ }^{7}$ in Slovenia, 2006-20098

\begin{tabular}{|l|c|c|c|c|}
\hline & No. of charges & $\begin{array}{c}\text { Filed indictment } \\
\text { act }\end{array}$ & $\begin{array}{c}\text { No. of persons } \\
\text { convicted }\end{array}$ & $\begin{array}{c}\text { Suspended } \\
\text { sentence }\end{array}$ \\
\hline 2006 & 6 & 3 & 1 & 1 \\
\hline 2007 & 12 & 5 & $/$ & $/$ \\
\hline 2008 & 21 & 10 & $2^{9}$ & 1 \\
\hline 2009 & 16 & 4 & $1^{10}$ & $/$ \\
\hline 2010 & 11 & 3 & 1 & 1 \\
\hline
\end{tabular}

Source: SORS, 2011

From the total number of 66 suspects, for which criminal proceedings at the state prosecutor have concluded in the relevant period, the prosecution concluded the proceedings without an indictment act for $62.12 \%$ of suspects and filed an indictment act for $37.88 \%$ of suspects (Table 3). In the period of 2006-2009 the courts have convicted 5 people, three of which were sanctioned with a warning - a suspended sentence of imprisonment (in 2006 a suspended sentence of imprisonment for up to 30 days, in 2010 a suspended sentence of imprisonment for 1-2 months and in 2008 a suspended sentence of imprisonment for 1-2 years). The courts did not pass any secondary sanctions ${ }^{11}$ or protective measures ${ }^{12}$. No convict commited a criminal offence in merger ${ }^{13}$, only one (in 2008) was a persistant offender

7 Proceeding concluded at the prosecutor office according to type of decision, as well as adult convicted persons (known perpetrators) and adult convicted persons with a suspended sentence (known perpetrators) according to a primary sanction, secondary sanction, a protective measure, persistent offenders and merger of offences.

8 Data for 2009 for criminal offences according to Article 318 of the PC and 315 of the PC-1 are combined.

9 Category "Other" (other sentences) is no longer published by SORS.

10 Category "Other" (other sentences) is no longer published by SORS.

11 Financial penalties are also considered as secondary sanctions.

12 Exclusion from public-sector employment and seizure of goods are also considered as protective measures.

13 A perpetrator committed a criminal offense in merger, if he/she committed two or more criminal offences within one or more offences, for which he/she is prosecuted simultaneously (Article 47 of the PC). 
(convicted of a second criminal offence) ${ }^{14}$ (SORS, 2011 and own calculation).

Now let us focus on the occurrence of criminal offences according to individual Articles, which show the endangerment of individual protected goods (SORS, 2011):

- For 13 suspects the prosecutor's office has concluded proceedings for intentional criminal offences according to paragraph 1, 9 of which have concluded the proceedings without an indictment act and 4 with a filed indictment act; for 9 suspects the proceedings have concluded for a criminal offence with severe consequences of intentional actions (paragraph 3 - physical injury or great pecuniary loss), for 5 of those the charge has been dropped and for 4 an indictment act was filed; proceedings for an intentional criminal offence with the most severe consequence (death) have been concluded for 3 suspects (for two the investigation was stopped and for one an indictment act was filed);

- For 19 suspects the prosecutor's office has concluded proceedings for criminal negligence (criminal offence according to paragraph 2), from which 12 suspects saw an end of proceedings with a dismissal, for 5 a criminal act was filed and proceedings have also been concluded for two unidentified individuals; for 19 suspects the proceedings have concluded for a criminal offence with severe consequences (physical injury or great pecuniary loss), for 9 of those suspects the proceedings concluded without an indictment act and for 10 suspects an indictment act was filed;

- Three convicted persons (in 2008, 2009 and 2010) were found guilty of criminal negligence (according to paragraph 2) and one (in 2006) of criminal negligence with severe consequences (physical injury);

- One convicted person (in 2008) was found guilty of the most severe form of criminal offence, intentional cause of death.

Rare occurrence of rulings for criminal offences suggests that legal practice is extremely rare and also applies to criminal offences committed

$14 \mathrm{~A}$ persistent offender is a perpetrator, who committed a criminal offence, after he has already been convicted with a final decision or has served the sentence or it has fallen under statute of limitation or has been relieved of his sentence (paragraph 3 of Article 41 of the PC). 
by a convicted construction contractor. ${ }^{15}$ Therefore we are able to conclude that the considered number of criminal offences by project leaders and supervisor, which have concluded with a final decision (and according to issued criminal sentences in the relevant period), is negligible.

\section{Economic consequences of supervisor's actions for the investor}

For the relationship between the investor and the supervisor it is very important that the investor signs a contract with the professional individual, in order to ensure that he/she achieves a final result within the investor's financial capabilities. Therefore choosing a manner in which this final result shall be achieved, is not up to the investor, but up to the professional individual (the supervisor). The professional individual cannot leave these decisions up to the investor, since this would be in contradiction with the basic purpose of the contract. But if they are left up to him/her, this does not also mean transferring risks, which are associated with such a decision (Plavšak, 1998, p. 18). But in the case of self-construction - until a construction log book shall be required - all risks, except ethical, moral or general social responsibility, shall continue to fall onto the investor, the non-professional or lay person.

It needs to be emphasized that the supervisor is liable for all direct damage, which a third party suffers and is a result of his actions and contractual obligations (Article 32 of the CA-1). The investor should therefore, by considering sufficient ethical-moral or social responsibility and with a direct analysis of costs and benefits, consider in the long term:

- the law stipulates that the investor also includes other professional participants (along with the project leader also the supervisor), which makes following legislation in force a realistic approach; in doing so, the investor rationally evaluates the benefits of avoiding participants and penalties by the Construction Inspector, if his/her illegal conduct is to be discovered (Klemenčič Manič et al., 201 1);

- to the investor a supervisor is a guarantee for successful and efficient execution of the order; in doing so, the investor compares the costs of a supervisor and the improved quality of construction;

15 A ruling by the Maribor Higher Court VSM30079 (Kp 122/2000). 
- in case of supervisor's violations the civil liability relationship is clear (the supervisor is liable to the investor). One or both professional organizations perform disciplinary actions, in case of violation of the CA-1, the Construction Inspector issues a fine for minor offence obligation to the supervisor, files a bill of indictment or declares a measure. In case of suspicion of an occurrence of a criminal offence, proceedings are carried out by other public authorities. As a rule, the investor should never suffer damages, since reimbursement is ensured by the supervisor's liability for damages. ${ }^{16}$ But nevertheless, this demands new investments in the form of time, transaction and opportunity costs for finding a new participant, in which trust plays a crucial role.

If the investor realizes a combination of supervision, as proposed by Duhovnik (2010, p. 145): »because the project leader may also be a supervisor, it would be less expensive, if the project leader would also perform the function of a supervisor", it is recommendable for the investor, to include construction participants in a quality, useful and socially responsible fashion.

Unfortunately data on inspections of self-constructed single-family houses do not exist, therefore estimates of irregularities (and supervisors' offences) in self-construction cannot be made. Also, the presentation of data by the Construction Inspectorate combines all data, inspections of all structures, buildings and also engineering structures (such as roads and similar).

According to Ritonja's estimates $(2006$, p. 6) there are $45 \%$ of singlefamily houses in Slovenia, for which natural persons received building permits and were self-constructed. With this in mind, we might speculate that the percentage of projects, which were prepared for natural persons for self-construction of new single-family houses, in 2008 was $28 \%$ of

\footnotetext{
$16 »$ In determining damage liability the victim must prove that the supervisor committed a certain illegal action, which may be a service or abandonment. Further on, he/she must prove that damages occurred to him/her and that they were a result of illegal actions of the supervisor. If just one of these propositions does not exist, there is no ground for damage liability.« (Dobnik, 2011, p. 10). This proving is quite difficult in case of selfconstruction, since a construction log book, a basis for recording findings, is not kept.
} 
projects for all new constructions (not only residential), in 2009 29\% and in $201030 \%$ (SORS, 2011 and own calculation). ${ }^{17}$

Less than a third of project documentation for buildings was therefore prepared for self-constructed single-family buildings. Unfortunately a brief review of self-construction practice in Slovenia (e.g. on an online forum podsvojostreho.net) suffices to reveal that investors in self-construction often do not possess any adequate nor sufficient skills. Most investors in self-construction of single-family houses order only the preparation of the project for ABP. And since they are building without the EP, often the only plan for construction is the architectural plan, which (even if it is prepared at an EP level) does not suffice for constructing a single-family house. The major part of project documentation for buildings in Slovenia is therefore prepared by architects, who may, in accordance with CA-1, perform "project-leader supervision". Since such a project leader for ABP is not directly liable for the fact that the construction investor does not possess the EP (as a performer of newly introduced "project-leader supervision" he/she only controls compliance with the project for $A B P$ ), this raises the question, whether the architect thus also avoided ethical-moral or social accountability. If he/she is present during construction (even if only as a "project-leader supervisor"), but works are performed without a project for $A B P$, this means that not even the basic condition for ensuring reliability of the constructed building (appropriate project documentation) is not fulfilled. If works are performed without a plan for structural constructions, electrical installations and equipment and machine equipment and installations, this means that they are carried out "on its own" and without a plan, which cannot ensure a final goal: the quality and reliability of the residential building. Potential rebuilding of poorly executed construction (and supervision) may present the investor with substantial additional costs.

17 In the years of 2006-2010 both natural and legal persons were in average annually granted 4,375 building permits for all types of new constructions, for new constructions of single-family houses the number is 3,048 or $70 \%$ of all permits for new constructions. During this period natural persons alone were in average annually granted 2,736 building permits for new construction of single-family houses or $63 \%$ of all permits for building constructions. Based on the findings of a research by Ritonja (2006, page 6) that natural persons annually self-construct at least $45 \%$ of all single-family houses, it is possible to estimate that during the period of 2006-2010 as much as $28 \%$ of all granted building permits for buildings referred to self-constructed single-family houses. 
The dilemma which we are facing in practice, is mainly whether the primary problem in Slovenia in the field of single-family house construction is allowing self-construction with unchanged legal regulation or bad supervision over land use or rather illicit (mainly inconsistent and dangerous) construction. In regard to the large number of constructions, monitoring of supervisors in Slovenia is insufficient (Klemenčič Manič et al., 2011 ) and the absence of public social accountability, combined with complex practice of introducing supervisors into the self-construction process, does not ensure safety and reliability of such construction. Therefore increased involvement of public authorities with modified rules for self-construction, as well as for supervision over the execution of works, is essential, since it is the only way to ensure safe residence in single-family houses.

Most of the times, the investor in a single-family house invests for the purpose of ensuring basic living conditions. Juvanec (2008, p. 18) believes that the attitude towards quality of construction is not directly associated with usage and that the investor influences the function of the building, but not the aesthetic side, unless he is well informed or wants something extra. He also believes that it is up to the personal culture of the investor, whether he/she shall choose the worst (or the best) solution in this circumstances or consciously excludes any factors in these circumstances.

\section{Conclusion}

Controlling bodies of professional organizations SCE and CAEP, as well as the building inspectorate, also determine ethical violations and supervisors' offences, which generally do not have any direct nor indirect effect on the investor, since:

- in respect of the number of considered disciplinary violations by professional organizations, we may confirm the findings of Kocjan (2011, p. 8), who distances himself from the (relatively small) number of reports, but believes: "...that the number of violations by authorized engineers is small in respect of the large number of members, which is definitely encouraging";

- Construction Inspectors annually issue an average of 50 decisions for all types of constructions (all types of building, as well as other structures), the numbers which were substantially increased in 2010, while the number of Construction Inspectors' measures as 
a minor offence authority were increasing in the period of 20062008 (to 64) and then decreasing until 2010, when it drops almost to the starting point in 2006 (to 27). Kovač (201 1, pp. 6$11)$ determines that in case of any doubt, it is necessary, according to the system function of inspections, to assume the explanation that the inspector is to act mainly as an administrative, not only as a minor offence authority, which is also most likely reflected in the number of measures taken against offences;

- if during consideration of paragraphs 1 and 2 of Article 318 of the PC (or 315 of the PC-1) we are able to question the occurrence of criminal conduct (which mainly depends on the vigilance of controlling bodies and prosecuting authorities), we are able to undisputedly state, while considering paragraph 3, that criminal conduct, which results in physical injury or death of a person (as the most important goods), is very rare.

Presented data confirm that an investor may trust the supervisor, but certain other issues remain unsolved, for which solutions and appropriate order must be found as soon as possible, in order to ensure overall social responsibility. A supervisor acts socially responsible and largely follows ethical-moral norms and provisions of positive law, but we are unable to claim - also in respect of the findings of Kovač (2010, pp. 6-9) - that the institutions of the national administration with their supervision system for the work of supervisors are effective and successful.

The question is also, what is the future of land use and of the security of self-constructed buildings, if believes and actions of all participants do not change. The legislator predicts that an investor in self-construction, who therefore assumes the role of the contractor, has appropriate knowledge and skills at his/her disposal. But this does not mean that the accountability for quality and safe construction falls solely onto the investor or the supervisor. The legislator's task should be preparing such regulations, which determine realistic tasks to mandatory participants and simultaneously propose adequate sanctions in case of illegal conduct. The basis for any sort of proof of occurred irregularities is keeping a construction log book, which may be avoided by investors in selfconstruction. Beside, the existing legal regulation uses fast-track proceedings for acquiring a building permit with fast-track inclusion of knowledge from only one field, architecture, while the essential part, the construction process, is generally no longer monitored in self-construction 
of single-family houses. Professional organizations (SCE and CAEP) should also, in the spirit of ensuring proper liability of their members towards investors, act more efficiently. A step in this direction was made by the SCE in April 2011, when its assembly adopted Instructions on Detailed Contents of Project Documentation (2011), because supposedly the majority of engineers believe: "...that it is necessary to improve the quality of engineering services, since numerous projects, which were signed by competent project leaders, and services performed by authorized engineers are bad and cast a bad shadow over the entire engineering profession."

There is sufficient offer for construction supervision services in selfconstruction. But the demand for these services is (too) small, since in practice such supervision is not considered as essential and paying for such services therefore actually presents a sunk cost. In order to ensure badly needed enforcement of self-construction supervision in practice, stimulation for further development of the offer of self-construction supervision services is required, so that builders will show interest for proper professional supervision. In case of (†oo) high supervision costs compared to the cost of preparing project documentation for acquiring a building permit, the introduction of mandatory self-construction supervision actually leads towards an opposite effect on the investors, who avoid supervision. This could be avoided with a sanction policy, but this is not the most desirable measure, since it would additionally prolong construction and increase costs.

In respect of a long tradition of self-construction and the estimated share in all single-family houses (45\%), it would be unreasonable (economically and socially) to abolish this type of construction. But in order to ensure a higher level of quality and consistency with the building permit, it would be appropriate to introduce a construction log book and to change the procedure and meaning of acquiring a building permit. We should once again introduce technical inspections of single-family houses, which were already brought to attention by the SCE (changes are most needed in the Rules on Design Documentation). Besides that, the acquired building permit should be a condition for receiving a house number (for registering the building). But defining greater accountability of the supervisor (this could partially be achieved by simply keeping a construction log book) and including different contractors into the construction process is urgent. The latter should act as inspectors 
of individual stages of construction and issue declarations of conformity. Along with declarations by the supervisor and the ABP project leader, the condition for acquiring a building permit should therefore also be such supporting documents issued by contractors as a proof of a building's reliability. It would be wise to also consider the effectiveness of sanctions, (in)appropriate amounts of fines in case of violating the provisions of CA- 1 and statutes of limitations.

Since there is no detailed data on the level of individual constructions or construction patterns, a detailed quantitative analysis is not possible at this point. Development of a more detailed database and using quantitative analysis methods present an opportunity for further research in the field of self-construction of single-family houses.

Mojca Klemenčič Manič is employed at a design company. She got her degree at the Faculty of Economics and Business in Maribor. Her field of research mainly covers the effect of relationships between investors and participants on the chronological and financial aspects of handling documentations for constructing single-family houses in Slovenia. She is a doctoral student at the Faculty of Management in Koper.

Zoran Cunk holds the position of a Senior Criminal Police Inspector at the Criminal Investigation Police Section of the Police Directorate Maribor. He graduated and received his masters' degree at the Faculty of Economics and Business in Maribor, where he is also a doctoral student. His fields of research and interest are: social responsibility, innovation management and criminal law and criminal procedure law.

Stefan Boinec is a professor of economics at the the Faculty of Management in Koper, the University of Primorska. His bibliography consists of approximately 970 units, over 155 of which are original scientific articles in scientific journals. He has received numerous awards. One of them was the Zois Recognition for Significant Achievements in the Field of Economics. 


\section{References}

- Bele, I. (2005). Zakon o prekrških (ZP-1) s komentarjem. Ljubljana: GV Založba.

- Breznik, J. \& Duhovnik, J. (2005). Uvodna pojasnila h komentariu. V: Zakon o graditvi objektov s komentarjem. Ljubliana: GV Založba.

- Breznik, J. (2010). Komentar k 45. členu ZGO-1: točka 1. In: Breznik, J. et al. Zakon o graditvi objektov (ZGO-1) s komentarjem. Ljubljana: GV Založba.

- CAEP - the Chamber of Architecture and Environmental Planning of Slovenia. Accessible at: http://www.zaps.si/ (18 July 201 1).

- Carroll, B. A. \& Buchholz, K. A. (2000). Business \& societys ethics and stokeholder management. 4th. Edition. Cincinnati (Ohio): South-Western College.

- Code of Professional Ethics for ECS Members. Accessible at: http://www.izs.si/fileadmin/dokumenti/pravilniki/Kodeks_poklicne_etike_IZSsprejet_na_skupini_IZS_15.6.2010.pdf (18. July 2011).

- Constitution of the Republic of Slovenia. OG of the RS, No. 33/91.

- Construction Act-CA-1, OG of the RS, No. 46/04 with modifications.

- Cunk, Z. (2010). Dinamični model družbene odgovornosti podjetja - model obče konsistentnosti. In: Mulej, M. \& Hrast, A. Eseji o družbeni odgovornosti. Maribor: Institute for the Development of Social Responsibility- IRDO and Ljubliana: Institute for Sustainable Development, Spatial Planning and Environmental Studies: Ypsilon Institute, Chapter 6.

- Deisinger, M. (2002). Kazenski zakonik s komentarjem: Special edition (p. 569). Ljubljana: GV Založba.

- Dobnik, C. (2011). Odgovornost nadzornika pri nadzoru nad izvajalcem in nadzoru nad izvajanjem del. IZS.NOVO 14(58), June 2011, 10-11.

- Duhovnik, J. (2010). Komentar k 45. členu ZGO-1: točka 8 in 9. In: Breznik, J. et al. Zakon o graditvi objektov (ZGO-1) s komentariem. Ljubljana: GV Založba.

- Instructions on Detailed Contents of Project Documentation. Accessible at: http://www.izs.si/inzenirska-zbornica-slovenije/akti/navodila-o-podrobnejsivsebini-projektne-dokumentacije/ (17 July 2011 ).

- Juvanec, B. (2008). Skladen razvoj med teorijo in odnosi. AR (2), 14-23.

- Klemenčič Manič, M., Cunk, Z. \& Bojnec, Š. (2011). Nelegalno ravnanje pri gradnii v lastni režiji: racionalnost investitorjev ali slabo delovanje institucii? IB revija $\mathrm{XLV}(4)$, in preparation for publishing. 
- Kocjan, B. (2011). Pogoj za obravnavanje kršitve je popolna prijava. IZS.NOVO 14(58), June 2011 , p. 8.

- Kovač, P. (2011). Inšpekcije med upravnim ukrepanjem in prekrškovnimi sankcijami. Pravna praksa (36), 22. 9. 2011.

- Leban, I. (2011). Sprememb je najbolj potreben Pravilnik o projektni dokumentaciii. Accessible at: http://www.izs.si/kniznica/glasiloizsnovo/letnik-2010/letnik-13-stevilka-55/programiprojekti/sprememb-jenajboli-potreben-pravilnik-o-projektni-dokumentaciii/ (1 7 July 2011 ).

- Mead, G. H. (1997). Mind, Self \& Society from the Standpoint of a Social Behaviorist. Ljubljana: Krtina (Slovene translation of fundamental works).

- Minor Offences Act, OG of the RS, No. 7-238/03 with modifications.

- Mulej, M. (2000). Dialektične in druge mehkosistemske teorije (podlaga za celovitost in uspeh managementa). Maribor: University of Maribor, Faculty of Economics and Business.

- $\quad$ Penal Code (Kazenski zakonik). OG of the RS, No. 63/94 with modifications.

- $\quad$ Penal Code (PC-1) (Kazenski zakonik (KZ-1)). OG of the RS, No. 55/2008 with modifications.

- Plavšak, N. (1998). Odgovornost profesionalnih oseb za napake gradnje: odgovornost projektanta, izvajalca in nadzornega inženirja. Ljubljana: Gospodarski vestnik.

- Report on the work of the Inspectorate of the Republic of Slovenia for the Environment and Spatial Planning for 2008, number 020-10/2009, January 2009. Accessible at:

http://www.iop.gov.si/fileadmin/iop.gov.si/pageuploads/IRSOP_dokumenti/ Porocilo_UZ/LETNO_POROCILO_20101_1_.pdf (2 April 2011).

- Report on the work of the Inspectorate of the Republic of Slovenia for the Environment and Spatial Planning for 2009, number 020-22/2010, March 2010. Accessible at:

http://www.iop.gov.si/fileadmin/iop.gov.si/pageuploads/IRSOP_dokumenti/ Porocilo_UZ/LETNO_POROCILO_20101_1_.pdf (2 April 2011)

- Report on the work of the Inspectorate of the Republic of Slovenia for the Environment and Spatial Planning for 2010, February 2011 . Accessible at: http://www.iop.gov.si/fileadmin/iop.gov.si/pageuploads/IRSOP_dokumenti/ Porocilo_UZ/LETNO_POROCILO_20101_1_.pdf (2 April 2011).

- Republic of Slovenia, Ministry of the Environment and Spatial Planning, Inspectorate of the RS for Environment and Spatial Planning, Head Office, Report on the work of the Inspectorate of the Republic of Slovenia for the Environment and Spatial Planning for 2006, number 020-8/2007, 
January 2007. Accessible at:

http://www.iop.gov.si/fileadmin/iop.gov.si/pageuploads/IRSOP_dokumenti/

Porocilo_UZ/LETNO_POROCILO_20101_1_.pdf (2 April 2011).

- Republic of Slovenia, Ministry of the Environment and Spatial Planning, Inspectorate of the RS for Environment and Spatial Planning, Head Office, Report on the work of the Inspectorate of the Republic of Slovenia for the Environment and Spatial Planning for 2007, number 020-10/2008, February 2008. Accessible at: http://www.iop.gov.si/fileadmin/iop.gov.si/pageuploads/IRSOP_dokumenti/ Porocilo_UZ/LETNO_POROCILO_20101_1_.pdf (2 April 2011).

- Rules on Construction Sites, OG of the RS, No. 55/2008, 54/2009.

- Ruling UL0003513 from 19 August 2010. Accessible at: http://www.sodisce.si/usrs/odlocitve/2010040815248030/ (18. 07. 201 1).

- Ruling UM0010386 from 22 September 2010. Accessible at: http://www.sodisce.si/usrs/odlocitve/2010040815248017/ (18 July 201 1).

- SCE - Slovenian Chamber of Engineers. Accessible at: http://www.izs.si/ (18 July 2011 1).

- Selinšek, L. (2007). Kazensko pravo: splošni del in osnove posebnega dela. Ljubliana: GV Založba.

- Slana, M. (2010). Investicijski procesi in vodenje projektov. Term-paper material for (professional) certification exams-amended 2nd edition. Liubliana: Slovenian Chamber of Engineers.

- SORS. Statistical Office of the RS. Accessible at: http://www.stat.si/ (2 July 2011).

- Tičar, B. \& Rakar, I. (2011). Pravo javnega sektoria. Maribor: Institute for Local Self-Government and Public Contracts.

- Tratar, B. (2005). Komentar k členom 45-58. In: Bele, I. Zakon o prekrških s komentarjem. Ljubljana: GV Založba. 